\title{
7 \\ Dispossession and Bottling after the Revolution
}

Mineral springs attracted renewed attention during the late nineteenth and early twentieth centuries. Artesian wells and expanding urban infrastructure produced an opulence of public water that enabled bathhouses to proliferate, reshaping bathing practices and socialities. At the same time, however, the homogenization of water actually boosted the value of heterogeneous waters, and investors turned to mineral springs with newfound interest. During the Porfiriato, spas and bathhouses were built and rebuilt in Guadalupe and Peñón, and new railroads brought tourists to baths in Aguascalientes, Topo Chico, and Tehuacán. In addition to the expanded bathhouses, entrepreneurs took advantage of widespread and longstanding ideas about the curative efficacy of mineral waters and opened bottling plants at those sites.

Historian Luis Aboites (1998) describes a long process between 1880 and 1946, facilitated in some ways by the Mexican Revolution, of expanding national-state control over water resources. The narrative of state centralization certainly captures much of Mexican water history, but I wish to narrow the focus on the mechanisms by which centralization proceeded. The history of the Tehuacán and Topo Chico mineral springs reveals the ultimate beneficiary of state centralization to be the private bottling industry, a process that might be more accurately called primitive accumulation. Karl Marx depicted this process as a violent rupture of customary property relations "written in the annals of history in letters of blood and fire." ${ }^{1}$ In twentieth-century Mexico, however, the dispossession of water resources was more often realized through legal and political mechanisms supported by technoscience, and the emergent fields of hydrology and hydraulic engineering were particularly important. ${ }^{2}$ This was a quotidian, cultural process involving the authority of certain 
kinds of argument, reasoning, and evidence, and an engagement with the bureaucratic procedures of the state. Also, while these waters were bottled for exchange in the marketplace, it was the assumption of heterogeneity and singularity-their culturally formed use-values - that drove their commoditization. ${ }^{3}$

\section{THE BUSINESS OF BOTTLING MINERAL WATERS}

Since the Middle Ages in Europe, pilgrims who could not make the long trip to springs such as Lourdes were still able to secure the effects by quaffing bottled water. Bottled mineral waters became increasingly common in the early nineteenth century in Europe and North America. Part of this was due to the expansion of transportation infrastructure that made it much cheaper to bring the curative waters to their hopeful consumers in the cities. Bottling was a business venture that was both profitable and promoted public health, yet did not require patients to visit the bathhouse. "The exportation of these waters great distances within the country is very easy," José Lobato pointed out in 1884, "and should be as beneficial to the sick people who are treated with this medicinal water by ingestion, as it is to the bottler who knows how to set up shops in the capital of every state."4 Another reason for this growth in bottling was that the local water sources in the growing cities were increasingly contaminated, and mineral waters bottled at faraway springs were less prone to contamination. Notions of the therapeutic character of diverse waters, as well as the unhealthfulness of the homogeneous water that was served through public pipes, bolstered the value of heterogeneous waters.

Ideas about why waters were curative, and how to administer them, increasingly favored bottling. By the 188 os doctors had concluded that the skin was an effective barrier to the absorption of minerals from water, and that the minerals in the waters needed to be delivered through inhalation and ingestion rather than bathing. In his study of mineral waters in Mexico, José Lobato describes inhalation techniques, pioneered in Germany, that required water to be "pulverized" into a mist(see earlier figure 10), or, if it was thermal water, that the steam be captured in a sauna-like "oven." Just as the new inhalation techniques required a specially designed apparatus, so too did the bottling of mineral waters. To maintain their mineral content, waters could not be exposed to the air, to light or any other impurity, nor agitated, heated, or subjected to changes in air pressure. A siphon was used to fill champagne bottles, stoppered with corks soaked in the mineral waters, and then coated with plaster. The bottling of mineral waters for drinking was thus a highly medicalized procedure that should, Lobato argued, be overseen and certified by a doctor.

At the same time that they were medicine, these early bottled mineral waters were also becoming food: they were the forerunners of the soft drinks we know today. Around 1800 a number of companies in Europe began to produce water with added $\mathrm{CO}_{2}$, and these gained favor for their taste and their medicinal qualities, and 


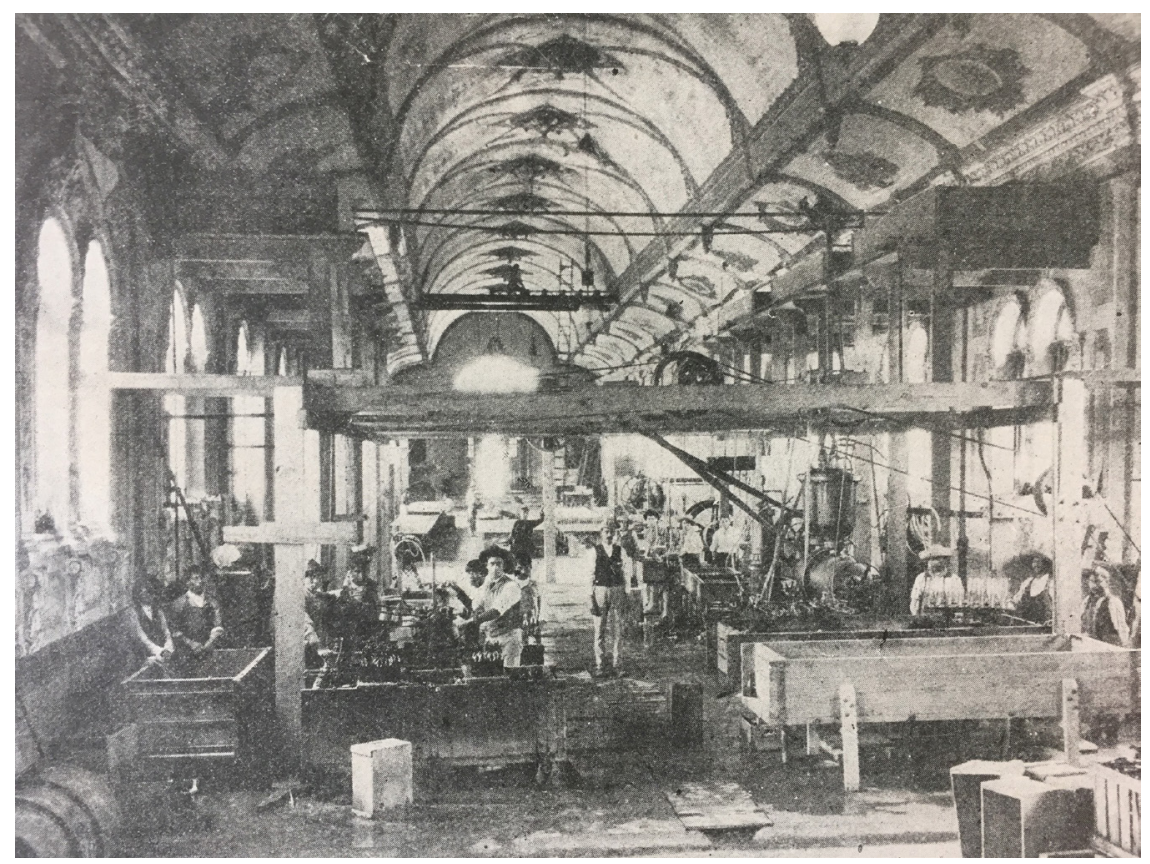

Figure 13. "Salón de embotellado de las Aguas." El Mundo Ilustrado 2, no. 12 (1906). With permission of Universidad Nacional Autónoma de México, Hemeroteca Nacional de México, Fondo Reservado.

were recommended for everyday use as table water. Other minerals, medicines, and drugs, such as strychnine, arsenic, quinine, and coca, were added to them by doctors, and it was also common to add sweet flavored syrup or to mix the concoction with white wine. Drinks were bottled with ever-larger amounts of sugar, part of a wider trend in the history of industrial society toward sweetened fast foods. Coca-Cola and other soft drinks based in "soda" waters (those mineral waters with carbonic acid and dissolved carbon dioxide) got their start at this intersection of medicine, fast food, and mass consumption. ${ }^{5}$

In Mexico, the industrial bottling of mineral waters for mass consumption began in the late nineteenth century, at the same time that the country's beer industry was founded. The sumptuous new spa at Peñón de los Baños featured a bottling plant, with the most modern and efficient machinery, using glass bottles that were produced in Monterrey's glass factories. José Lobato was a foremost proponent of bottled mineral waters for medicinal purposes, and he urged doctors and bottlers not to add red wine or other substances that would change the mineral makeup of the waters. Peñón produced plain mineral water at its plant at the bathhouse, and the Compañía Explotadora de los Manantiales del Peñón stored the bottles at its 
warehouse in downtown Mexico City, on Donceles Street, before shipping them out to consumers. The "Aguas Minerales del Peñón” traveled widely, earning customers across Mexico and, in competition with other mineral waters, a gold medal in the Saint Louis Exposition of 1904. It did not hurt that the medicinal qualities of Peñón's waters came recommended by Eduardo Liceaga. ${ }^{6}$ Mineral springs, a key element of modern bathing, also figured prominently in the emergence of mass consumption of industrial products.

TEHUACÁN: STATE POWER AND THE CONSOLIDATION OF THE BOTTLING INDUSTRY

Tehuacán, Puebla, was not far behind Peñón in the popularity of its bottled waters during the Porfiriato, and after the revolution it quickly eclipsed Peñón. For centuries the town lured patients seeking a cure from kidney stones and other maladies, and since the 1890 s the plush hotel and balneario "El Riego" received visitors by train from Mexico City and Puebla who sought an exclusive and therapeutic mineral waters treatment with baths and drinking fountains. Like Peñon de los Baños, the town's springs were promoted by the scientific community and the Secretaría de Fomento during the Porfiriato, and a tram connected El Riego to the local train station. By the early 1920s a half-dozen hotels and three bathhouses served visitors of all social strata, and Tehuacán became the foremost watering place for Mexican state officials. ${ }^{7}$ This was due in large part to the influence of President Plutarco Elias Calles (1924-28), who made Tehuacán's HotelSpa El Riego a second home, occasionally even holding cabinet meetings there. Thousands of visitors synchronized their leisure choices with those of Calles and his senior officials.

The presence of the postrevolutionary government in Tehuacán soon turned into scrutiny of the healthfulness of the town's mineral waters, and in particular, its bottling industry. In the late 1920 s the Departamento de Salubridad Pública made a concerted effort to regulate the production of mineral waters (aguas minerales), sparkling waters (aguas gaseosas), and soft drinks (refrescos). Salubridad Pública carried forward the Porfirian preoccupation with microbiology almost without pause during the revolution, and this knowledge of bacteria, amoebas, and other vectors of disease combined with much older ideas about the curative properties of particular waters to produce the conclusion that waters could hurt as well as heal. The business of bottling originally grew around mineral waters and their promise to cure, but bottled drinking water soon became desired for its purported purity, displacing in wealthy households the water delivered by urban water systems and water carriers. By the 1920s, bottled water had expanded into a thriving cottage industry producing many varieties of sweetened and carbonated waters that most often did not employ mineral waters at all. The multiplication of industrial bottled drinks resonated with deep-seated assumptions about the benefits and value of 
heterogeneous waters, but attracted the attention of public health officials worried about the potential harm these waters could cause.

Businessmen had been shipping Tehuacán's mineral water to Puebla and Mexico City since the late 1800 s. It was initially used as a form of medicine, in line with centuries of practice of bathing in and drinking mineral waters for their curative properties, and was sold in boticas (pharmacies) alongside other curative waters. With the construction of the train, the water was much easier to transport, and large bottles (garrafones) of water were "shipped daily" for use "in all parts of Mexico, in houses, hotels, cantinas." ${ }^{8}$ During the revolution, the largest of these bottling plants, the Cruz Roja and the San Lorenzo Mineral Water Company, were ransacked and burned, and labor mobilization troubled the industry in the 1920 s. $^{9}$ In this context an array of smaller companies with improvised production methods and lax sanitary control sprouted up alongside a half-dozen bigger, more established ones. Tehuacán's bottlers continued to ship garrafones of drinking water to clients in Mexico City such as President Emilio Portes Gil, but doubts about quality attracted the regulatory action of Salubridad Pública.

On July 30, 1927, Salubridad Pública sent notice to Tehuacán's bottlers that they were prohibited from selling water until they could comply with Article 246 of the Sanitary Code requiring that bottled waters be free from biological contamination, and the National Railroad was ordered not to accept any water for shipment. ${ }^{10}$ The Montt family, owners of the El Riego hotel, told the National Public Health Department (Salubridad Pública) that they bottled water from their spring only so it could be used to cure patients, but Salubridad responded that the number of E. coli bacteria discovered in the water bottled by them and many other companies in Tehuacán was dangerous to those patients. ${ }^{11}$ Salubridad Pública officials made visits to the factories and found many of them to be lacking basic requirements of hygiene, with inferior capping machines and no machinery for sterilizing the water. Some bottlers ignored the ruling and continued to bottle waters and refrescos, but most shuttered their doors. ${ }^{12}$ The municipal government of Tehuacán responded to the crisis in confidence toward Tehuacán's waters by arguing that "everyone in the country knows that the only thing that gives life to this city are the curative virtues of its waters," and that for years the town had been building up its credit and prestige among doctors and visitors. ${ }^{13}$ But tourists, convinced that the waters were more harmful than curative, stayed away.

To address the problems with sanitation and hygiene, the bigger bottlers agreed to comply with national health codes by building infrastructure to capture and convey the mineral waters from the springs. After negotiating with Salubridad Pública, the companies installed a system of covered concrete canals that began at the springs and carried water to the area of town where the bottlers were. The municipal government of Tehuacán also raised funds from the state and federal governments to rebuild its own local water distribution system. By November all of the major bottlers had installed capping machines, and these were inspected and 


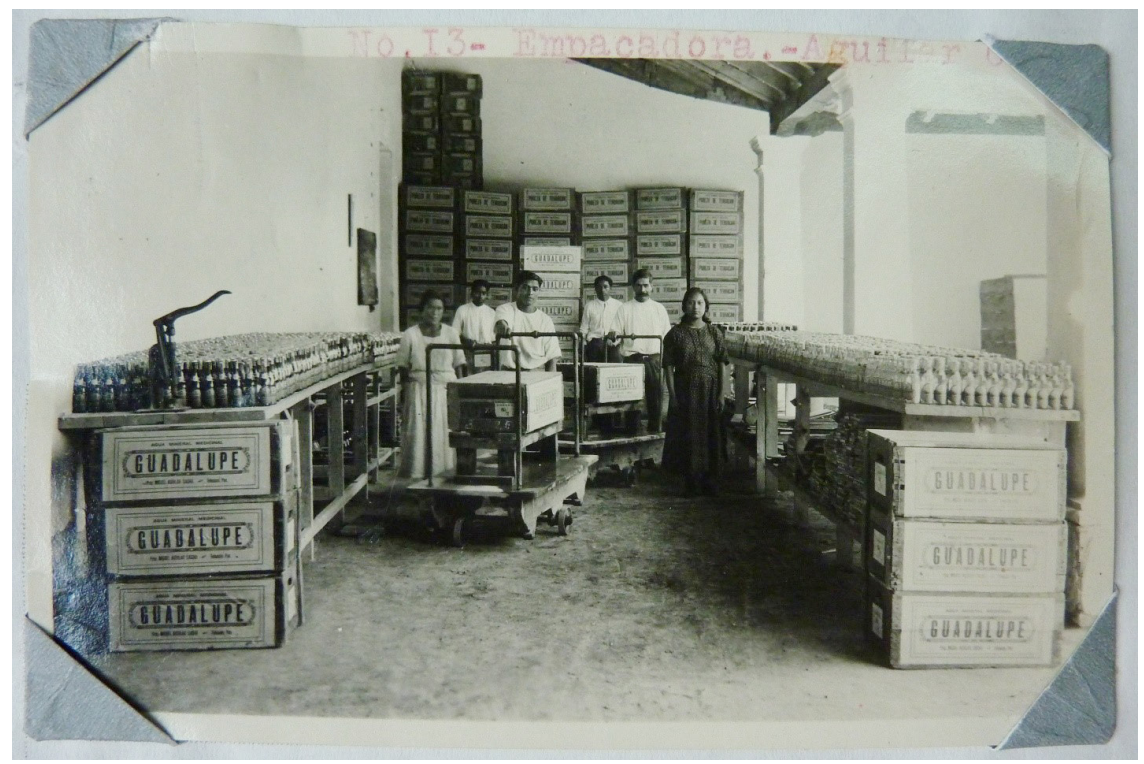

FIgURE 14. "Empacadora-Aguilar Cacho." With permission of the Archivo Histórico de la Secretaría de Salud, Mexico City, Mexico. AHSS, FSP, SSJ, Caja 9, Exp. 1. Note the new capping machine.

certified by Salubridad Pública. ${ }^{14}$ In addition, the bottlers agreed that Salubridad would train and certify the workers in hygienic practices, and that all products would be labeled with the date of production. ${ }^{15}$ The bottlers coordinated efforts to raise money for the works, and installed automated production systems to reduce human contact with the water and the bottles. However, they asked in exchange that the federal government prohibit and prosecute the production of unregulated artisanal bottled water, the use of labels that falsely advertised bottles as Tehuacán mineral water, as well as the importation of foreign mineral waters. ${ }^{16}$

Salubridad Pública's intervention in the business of bottling extended through the early 1930s, and resulted in a consolidation of the bottling industry, with fewer artisanal producers and a narrower range of waters available to the public. Over previous decades sparkling waters (gaseosas), lemonades, and other sweetened drinks (refrescos) had proliferated, and there were, according to a spokesman for the bottling industry, "an infinite number of clandestine factories that supply the public with products of a terrible quality. ${ }^{{ }^{17}}$ Often these were advertised as mineral waters but were not, and many used saccharine produced in the United States by Monsanto and imported illegally. ${ }^{18}$ The government stepped in to control the variable quality of these waters, to the glee of large bottlers and the sugar industry. Zealous agents of Salubridad Pública sent samples to their central laboratory, then 
fined and closed offending factories in Mexico City, Tehuacán, Tampico, Cuautla, Aguascalientes, Tepic, Tuxtla Gutiérrez, Nuevo Laredo, and elsewhere for using saccharine, saponin, and salicylic acid in their refrescos, and for labeling refrescos as mineral waters. ${ }^{19}$ In Tehuacán, the larger bottlers that could afford to comply with the regulations banded together to improve their infrastructure and resume production, simultaneously benefitting from the state's elimination of competitors. In Topo Chico, investment by the Coca-Cola Company provided capital for upgrading the bottling plant, allowing it to thrive in the new environment of sanitary regulation (see next section). In 1934 alone, hundreds of cases of adulteration were prosecuted by the new "Sanitary Police" of Salubridad Pública, an effort that resulted in "almost eradicating the once-frequent adulteration of drinks, especially sparkling waters and pulque." ${ }^{20}$

To support their effort to police the heterogeneity of waters in Mexico, Salubridad Pública mounted a propaganda campaign in the pages of the Mexico City daily El Universal, with articles by bottlers, lawyers, and doctors. ${ }^{21}$ Arturo Mundet, creator of the classic apple-flavored soft drink Sidral Mundet, argued that the sugar which bottling companies put in soft drinks made them healthful, because sugar is a preservative and provides calories. That the legitimate soft drink companies used sugar was ensured by agents of Salubridad Pública monitoring their factories, and El Universal alerted the public that because of the cost of sugar, any refresco that sold for less than six cents a bottle was certain to contain saccharine or some other artificial sweetener. ${ }^{22}$ Various articles in the El Universal presented cases of children intoxicated by unsanitary sweets while playing in Chapultepec Park, such as one-year-old Raúl Arriola, who died after drinking a bad artisanal soft drink. Raúl's sad story was evidence, El Universal argued, of the need for "strict vigilance of the streets and public spaces" by Sanitary Police. ${ }^{23}$

Salubridad Pública's policing of bottled waters happened at the same time that it embarked on a wider effort to ensure water quality in municipal and rural water systems across Mexico. Potable water and drainage systems were constructed with Salubridad's oversight and financing, and President Lázaro Cárdenas (1934-40) planned to almost double the portion of the national budget dedicated to Salubridad during his term, from 3 percent in 1933 to 5.5 percent in 1939. In 1935 Cárdenas authorized the Secretaría de Hacienda y Credito Publico to provide 5.5 million pesos for "supplying potable water to towns of less than twenty-five thousand inhabitants." ${ }^{24}$ The hydraulic infrastructure promoted by Salubridad Pública delivered a singular, sanitized public water, an effort analogous to its policing of bottled waters.

\section{TOPO CHICO: THE SCIENCE OF DISPOSSESSION}

The history of the mineral springs in Topo Chico, Nuevo León, provides an example of how state hydrologists and engineers facilitated the transfer of waters from peasants to industrial capitalists. Congregación San Bernabe Topo Chico was a 


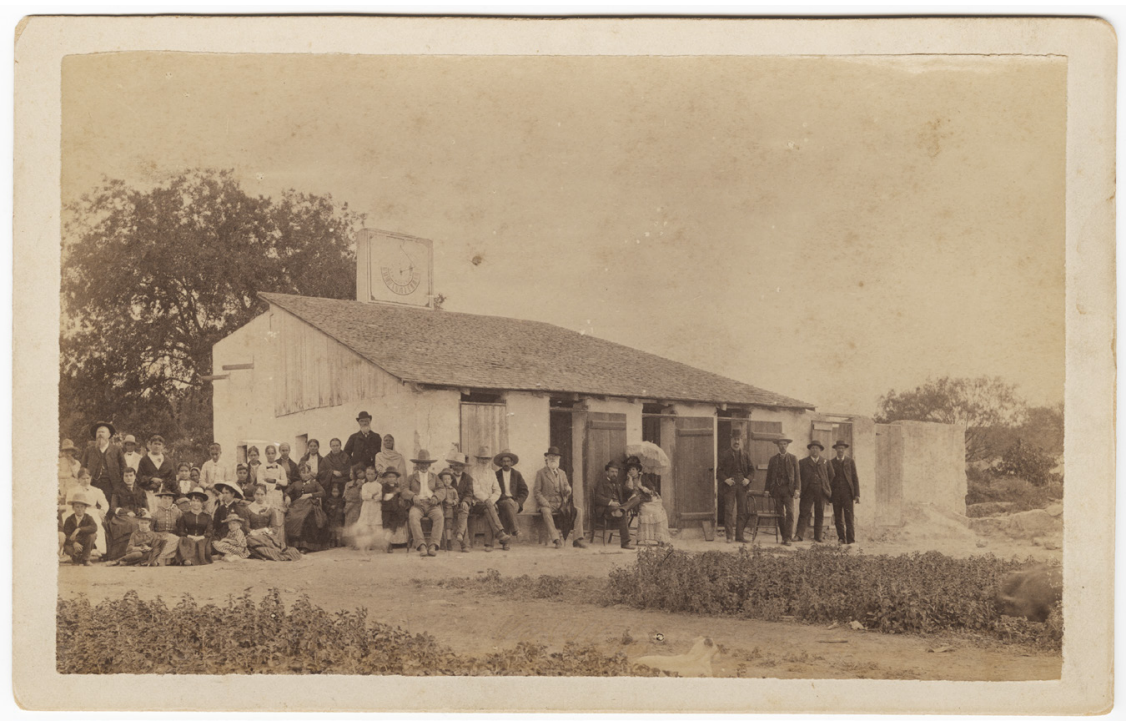

FIGURE 15. Topo Chico bathhouse, c. 1890. With permission of DeGolyer Library, Southern Methodist University, Dallas, Texas. AG1987; 0643.

small town situated in a large expanse of dry ranchlands in northeastern Mexico that was awarded by the Spanish crown to Captain Lucas González Hidalgo in 1716. Residents passed the years tending livestock and farming a small cluster of fields irrigated by the waters from two local springs, a hot spring known as "Agua Caliente" and a warm spring called "Ojo Caliente." A third spring, "La Saca," issued cold freshwater but only really flowed when it rained. The springwater was scant, hot, and carried minerals, but it flowed steadily and did not hurt their fields. The water was fine for cleaning dishes and houses, and people agreed that there were therapeutic benefits from drinking and bathing in it. There was never enough water, of course, for all those who wished to use it, but while quarrels over water were common the town managed the resource in a communal fashion.

This all began to change with the building of the bathhouse in Topo Chico in 1882, and the arrival of a stream of visitors from the United States. The western United States, taken from Mexico by force in 1848 , was an especially attractive destination for urbanites from the Eastern Seaboard who traveled seeking the health benefits they perceived would be gained from fresh air, wide-open spaces, and a more immediate interaction with the natural world. ${ }^{25}$ Mineral springs, long valued for their therapeutic dimensions, were among the first places claimed, settled, and developed by the newcomers. In Texas, for example, hundreds of mineral spring resorts enjoyed a boom between 1860 and 1920 , peaking in popularity around 1900. ${ }^{26}$ The expansion of mineral and hot springs resorts across the southwest 
United States was facilitated by railroad companies, which often developed the hot springs nearby their newly constructed lines.

The construction of railroads in Mexico in the 188 os enabled visitors to travel from Texas all the way to Mexico City, and Mexican mineral springs were important destinations for Americans seeking cures and seeing the sights. ${ }^{27}$ Aguascalientesnamed after the famous hot waters located there-attracted the interest of almost everyone riding the train from the northern border down to Mexico City, and traveler accounts from the time go into detail about the bathhouses and bathers of that city (see chapter 5 ) ${ }^{28}$ In the border state of Chihuahua, the Atchison, Topeka, and Santa Fe line built a connection to the hot springs of Santa Rosalia, ${ }^{29}$ and various efforts were made between 1900 and 1932 to develop the springs just south of the border in San Antonio, Chihuahua, in order to attract gringo tourists. ${ }^{30}$

The encroachment on hot springs in northern Mexico by new actors and ideas was especially notable in the small settlement of Congregación San Bernabé Topo Chico. For most of the town's history the waters of the Ojo Caliente were left to run their course, and it was not until around 1850 that townspeople constructed a sixby-twelve-meter pool out of stone and cement to store water, and a springhouse to protect the source. The pool supported the traditional domestic and agricultural uses, but also enabled a new use-bathing - especially by those arriving from afar with clear ideas about the therapeutic properties of the waters. Locals charged these health seekers a few cents for access to the reservoir, but shared no common opinion about the desirability of developing the hot springs for bathing tourism. ${ }^{31}$ Regardless, the interest of the outsiders in the medicinal properties of the waters was keen, and their efforts to establish a business with the mineral waters were supported by Bernardo Reyes, provisional governor of Nuevo León. At Reyes's coaxing, the townspeople met and hashed out a forty-year deal by which their waters were concessioned to American Emma Slayden, who was required to build a bathhouse and provide other amenities. Four years later, A.C. Schryver of Waco, Texas, took over the contract, and hired community members to build that bathhouse using water from the Agua Caliente spring, thus creating the Compañía de Baños Topo Chico. Bernardo Reyes also awarded Schryver a concession for a mule-drawn railroad linking Topo Chico to Monterrey.

Schryver got the money to build the railroad from expatriate American financier and Monterrey resident Jules A. Randle. ${ }^{32}$ Randle inherited the wealth of a slaveowning family from Georgia that moved to Texas just after the Mexican-American war to run a cotton plantation. He fought in the Confederate army, and upon surrender moved back to the family plantation on the Brazos River in Texas, which became one of the largest cotton farms in the region. His arrival in Monterrey in 1881 made him one of northern Mexico's largest capitalists, investing in urban railroads, properties around Monterrey, and silver mines. He was president and owner of the Monterrey and Santa Catalina Railroad and the Topo Chico Hot Springs Railroad, and owned one-quarter of the enormous Rosario Silver Mining Company. ${ }^{33}$ 
With the capital of Randle and others the business of bathing in Topo Chico was up and running. The new bathhouse had a men's area and women's area, each with its own pool 13 meters long, 5 meters wide, and 1.8 meters deep. Each of the two areas also had twelve tubs, fabricated of wood and zinc, each in its own 3-by-2.5-meter wooden stall with a wood and cloth cot. Admission to the bath, including the 45-minute, three-mile tram ride from downtown Monterrey, was 50 cents. Nearby, another group of Americans built a luxurious hotel to cater to the American tourists, with a kitchen run by an American chef. In 1893 E.R. Glass built the Hotel Marmól across the street from the bathhouse to cater to the new influx of visitors to the hot springs, by then known regionally, nationally, and internationally for their curative properties. ${ }^{34}$ Jules Randle invested some of his silver fortune in the \$250,000 Hotel Marmól..$^{35}$

A number of German and American doctors arrived to Topo Chico to offer their services to health-seekers using the waters. ${ }^{36}$ One of these, Dr. G.F. Brooks, moved from the paradigmatic mineral springs town of Hot Springs, Arkansas, to try his luck at this emerging tourist health spa. ${ }^{37}$ So widely known were the springs that J.H. Blackburn, a doctor from Texas searching for a cure for his gout and diabetes, included Topo Chico in an itinerary that also listed far-flung mineral water health resorts such as Lithia Springs, Virginia, and Hot Springs, Arkansas. ${ }^{38}$ The Mexican National Railroad Company, which connected the United States to Monterrey and the local Topo Chico tramway, distributed a free booklet promoting "Tropical Tours to Toltec Towns," and highlighted Topo Chico's "superb baths and a good hotel, all under American management." 39 The town of Topo Chico quickly became a mecca for American visitors, giving rise to a host of peripheral services, such as a local dairy run by American settlers. One visitor noted that "the whole settlement" of Topo Chico was "managed by Americans." ${ }^{\circ}$

Bottling was an equally important business at Topo Chico that grew to eventually displace the bathhouse in the 1930s. The waters of Topo Chico achieved such fame during the last decades of the nineteenth century that Randle contracted the rights to six liters per second of the springflow from the community of Topo Chico and began bottling the mineral water under the brand name of Topo Chico for distribution to visitors and inhabitants of the region. ${ }^{41}$ In 1900 the community of Topo Chico signed a contract giving permission to Emma Slayden to build a bottling plant, although still in 1902 a traveler noted that "the springs themselves stand in a shady grove" and were not captured by a bottling plant at their origin. ${ }^{42}$ Emilio Hellión, a Frenchman residing in Monterrey, bought into the Topo Chico bottling company and, together with Manuel Cantú Treviño, secured capital from the New York firm Wilson and Company to expand and consolidate the operation..$^{43}$ At the same time, Pedro Treviño, one of San Bernabé Topo Chico's wealthy landowners and owner of the ephemeral La Saca spring, built a spring house and factory for ice and soda, investing upward of 100,000 pesos. Much of this money likely came from outside investors. 
Conflicts emerged as bottling intensified. Treviño's development of the La Saca spring was opposed by members of the community, and as a result of their complaints an expert in hydrology was sent by the city government of Monterrey to investigate. Because he had dug a well and the springwater did not flow beyond his property, Treviño was found to be the legal owner of the spring. This first conflict over the springs set the tone for the competing social uses and politics of these springs during the next forty years, which would continue to be characterized by divisions within the community and a major role for government scientists in determining the nature of the water resources, and in transferring control and use to capital. ${ }^{44}$

As bathing and bottling grew in popularity at the end of the nineteenth century information was needed to govern competition over mineral springs. The emergent science of hydrology assumed the task of determining if water was property of the nation, the state of Nuevo León, or private landowners. During the rule of Porfirio Díaz (1880-1911) the government made an effort to map the Mexican countryside, and distributed lands to surveying companies to promote this activity. ${ }^{45}$ Despite these actions, small water sources such as hot springs remained under the radar of the state. For example, in 1904 local residents asked the secretary of agriculture and development for rights to build a bathhouse at the hot springs in Las Cabras, Chihuahua, but the federal government could not even find those hot springs on their map. ${ }^{46}$ In the case of the hot springs near Catemaco, Veracruz, the Secretaría de Obras Públicas did not possess a map of the region, let alone of the springs, and could not acquire one from any other branch of government. ${ }^{47}$ Even when the government's own maps registered hot springs, and those springs were located on federal lands, officials usually had no information about spring flow, temperature, established uses, or anything else.

The waters of Topo Chico attracted the attention of regional and international capital, and their status as a community resource was challenged. In 1898 the national government declared the waters of the drainage where the Topo Chico springs were located-the Arroyo Topo Chico-to be national waters, because they led to the Santa Catarina River, which eventually emptied into the Río Bravo. ${ }^{48}$ This was confirmed, at least on paper, by a map from 1904, although the community of Topo Chico continued to dispose of "its" hot springs in the ways established during the previous centuries: for domestic use and gardens, for animals, and for bathing. The recent turn to concessioning the waters to bottling and bath companies did not put into question community ownership over the resource. ${ }^{49}$ During the revolution, popular ideas about "land and liberty" reinforced local control of the hot springs and in 1917, a new Constitution was written which enshrined the radical liberal idea that the land should belong to those who worked it. In 1918, with local agrarian rebels in charge of the bathhouse, the waters of the drainage in which the Topo Chico hot springs were located were ruled to be private rather than national waters. This ruling validated the existing contract 
between the Community of San Bernabé Topo Chico and the bottling and bath companies, and short-circuited the possibility that the waters would be nationalized by the federal government. ${ }^{\circ}$

Nature in northern Mexico did not submit readily to the scientists, for the arid landscape did not conform to hydrological concepts such as "river." Water often only flowed during the rainy season, and small drainages (arroyos) such as that of Topo Chico would only carry water during storms. The same maps that failed to register hot springs depicted flowing rivers that were in reality simply drainages that hardly ever carried surface water. Furthermore, water laws written before the rise of hydrological science did not contemplate the connections between the surface waters and subsoil waters, ${ }^{51}$ and Mexico's constitution only incorporated groundwater in 1945 , with a reform to Article $27^{52}$ To complicate this issue, the waters of hot springs, which emerge from deep below the surface of the earth, usually have little to do with those that run in drainages either as subsoil water or surface water.

Water was considered a common-pool resource in Mexico before and after the revolution, as the postrevolutionary state incorporated popular concepts of common property of land and water into the new Constitution of 1917. But who had the authority to designate the legitimate users of that common property? The answer involves issues of scale and scientific authority. Mexican water administration was organized legally by a principle of geographical scale. Water that did not flow beyond the boundaries of a single property was considered part of that property. Water that flowed across different properties but not across a state's borders was under the jurisdiction of that state's government. That which crossed state lines, such as the water carried by the Salado and San Juan rivers and their tributaries, was national; if a river drained into the Río Bravo (known as the Río Grande in the United States) it was water governed by international treaties as well. All national water was the common property of the nation, to be administered by the federal government, and during the revolutionary and postrevolutionary period, water, like land, was the object of nationalization and redistribution by the federal government. These were scales of government, and obviously political.

Science supported the slow process of primitive accumulation and the transition from peasant uses of water to capitalist uses. In Topo Chico, a local spring that in 1880 supported diverse economic activities of peasant households was, by 1950 , completely utilized by one the biggest industrial bottling companies in Mexico and the world. Rather than hinder it, the long process of revolution (1910-20) and postrevolutionary state formation ushered along the process of accumulation by dispossession. The armies and leaders of this conflict formed constantly shifting alliances, and communities were divided along these lines. In Topo Chico the revolution fractured existing agreements about the legitimate uses and owners of the spring waters, and a group of rebels rose in opposition to those in the community who dominated the land and water and controlled the town government. As the 


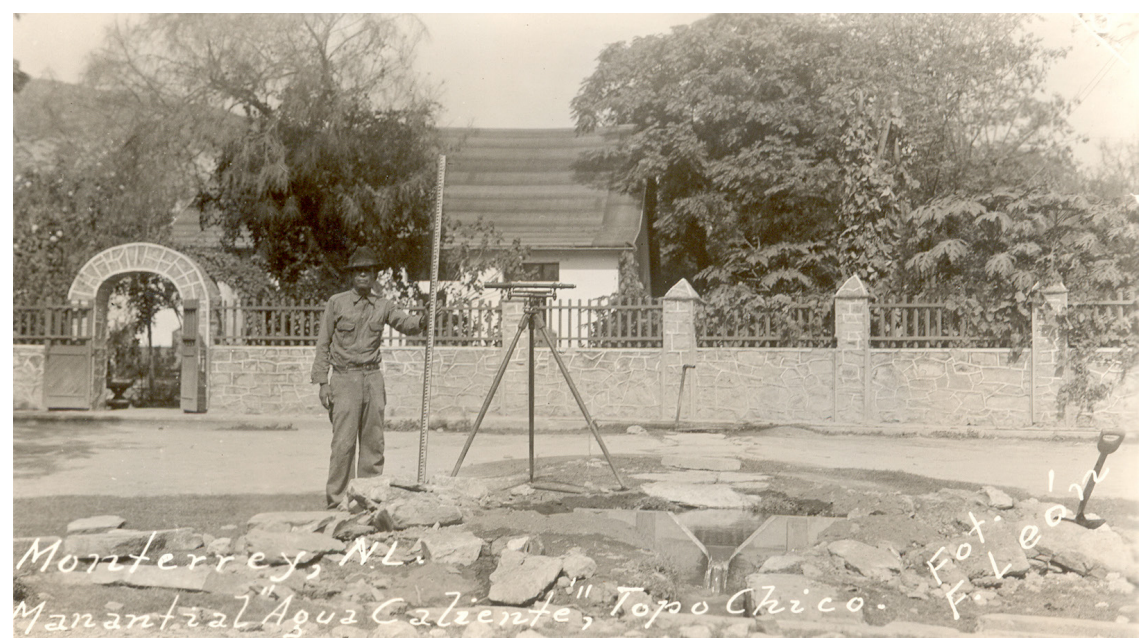

Figure 16. "Manantial Agua Caliente," c. 1930. With permission of the Archivo Histórico del Agua, Mexico City, Mexico. AHA, AN, Caja 463, Exp. 4893.

revolutionary movement across northern Mexico died down, and the victorious generals began the process of rebuilding the Mexican state, the local rebels of Topo Chico adopted the politics of agrarian reform (agrarismo), pressing the federal government to nationalize land and water held by the wealthier members of the community and award it to them as a collective farm, or ejido.

The social upheaval wrought important changes to the bathing and bottling businesses that used Topo Chico springwater. Pedro Treviño's ice and soda factory, which utilized the La Saca spring, was abandoned, and the foreign investors in the Topo Chico bottling company fled, selling their stakes to regional businessmen Manuel Barragán and Leónides Páez. The Compañía de Baños met the same fate when the national and international tourism that had supported the bathhouse and hotel ceased completely because of the violence. In 1921, in one of its first actions, the newly constituted Department of Public Health (Salubridad Pública) closed the baths, citing the unhygienic state of the facilities.

In 1922, the contract between the town of San Bernabe Topo Chico (still the holder of legal rights to the hot springs water) and the Compañía de Baños expired..$^{53}$ Without a contract for the waters, without a bathhouse in condition to receive customers, and without customers brave enough to visit Topo Chico, the Compañía de Baños went out of business and the installations were taken over by agraristas. They, however, had no means with which to improve or maintain the infrastructure of the baths, and soon "the roofs were falling and the tubs, walls and pipes were so deteriorated and filthy that very few people dared use them." ${ }^{54}$ In the turmoil, the town government asserted itself, taking over the administration 
of the hot springs water "by the unanimous will of the neighbors and community members who live in Topo Chico." 55 In an effort to force the bottling company to agree to a new contract, the town government cut off water to the bottling plant and took out advertisements in the newspapers of Monterrey accusing the company of bottling regular water, not mineral water. ${ }^{56}$ Soon after, the town government delivered a petition to the federal government in which it claimed to be the rightful owner of the mineral springwater and asked that it be returned. In 1924 the town reopened the baths under its own control after correcting the problems cited by Salubridad Pública. ${ }^{57}$

The struggle over land and water in Topo Chico proceeded in fits and starts, and different levels of government intervened on behalf of different actors. To deal with the agrarista uprising, in December of 1923 the governor of the state of Nuevo León orchestrated a land transfer outside of the federal agrarian reform process aimed at establishing peace between the competing factions in the town. A transfer shifted 1,444 hectares of land acquired by large landowners in the midnineteenth century to the agraristas, but before this agreement was signed into state law in March 1925, the community submitted a parallel request to the federal government's Agrarian Reform Commission (CNA) for the return of those same lands, claiming that the Congregación San Bernabé once owned them. The local branch of the federal government approved the request, but it was rejected at the state level by the governor of Nuevo León, who had already brokered a similar reform. Pressured by the federal government, the state government eventually approved the federal creation of an ejido as a new concession of land rather than a return of land. In August of 1926 President Plutarco Elias Calles declared a resolution awarding the ejido, and thereby annulling the state of Nuevo León's 1923 agreement. ${ }^{58}$ This award of land rejected the community's ancestral claim to the resource, and reinforced the federal government's position that it was the only legitimate owner and administrator of national land and water.

Once the land was delivered, the struggle turned to water, and was fought on the terrain of hydrology. The central problem was that there was not enough water to irrigate the newly distributed lands. The Presidential Resolution of 1926 parceled out 25 hectares of gardens and orchards near the town, and 2 liters per second of water from the hot springs for domestic uses and for livestock, but did not provide the 7.9 liters per second of water needed to irrigate those 25 hectares. A bigger problem, however was that the resolution also failed to provide the 73.2 liters per second of water needed to irrigate the 1,444 hectares of previously unirrigated lands that was also part of the distribution. ${ }^{59}$ With the hope of resolving this problem, the community of Topo Chico petitioned the secretary of agriculture to declare the waters of the Arroyo Topo Chico national, and not private, so that they might lodge a claim to them through the federal government's agrarian reform process. $^{60}$ The secretary of agriculture sent an engineer to make a study (the second) of the springs and the Arroyo Topo Chico into which they drained, and in 
June of 1927 the waters of the arroyo, including the springwaters, were indeed declared national property because, the engineer argued, the waters formed part of a drainage that eventually led to the Río Bravo. ${ }^{61}$ Once placed under control of the federal government, the issue turned to whom the federal government would award their use.

When the hot springs waters were nationalized (for the second time), the local town government of San Bernabe Topo Chico immediately took over the bathhouse. Its leader, Celso Cepeda, asked permission from the federal government to "make use of the hot water for the public baths that [the town] will refurbish using money from the agrarian bank." ${ }_{62}$ The town government then squared off against the Compañía de Baños Topo Chico, accusing it of never paying the monthly charge for the waters of 100 pesos that was stipulated in the contract. The Compañía countered with the opposite claim: that it had been paying the 100 pesos to Cepeda for some time. ${ }^{63}$ Then, in March of 1928, the ejidatarios of Topo Chico occupied the bathhouse. ${ }^{64}$ The state government of Nuevo León immediately intervened, ordering the Congregación to return the facilities to J.T. Garza, proprietor of the Compañía de Baños. ${ }^{65}$ The state government declared that the ejidatarios did not have permission to use the waters for industrial purposes, and the Compañía de Baños could therefore continue to use them for bathing and bottling. ${ }^{66}$ This decision was based on the assertion that the hot springs were local waters rather than federal waters. ${ }^{67}$ The federal government protested to the state that "the declaration of Arroyo Topo Chico as national waters would not be reconsidered." 68

The state government continued to assert its right to manage both the Topo Chico springs and the conflicts surrounding them, brokering a deal between the town of Topo Chico and the Compañía de Baños de Topo Chico and its operator, J.T. Garza. In a twenty-year contract signed in May of 1928, the town was declared owner of the bathhouse, with its baths and offices, as well as a nearby park and bandshell and various other properties. These facilities were to be rented by the Compañía de Baños Topo Chico for 100 pesos a month. The waters of the hot springs were to be used only for the bathhouse, and then sent to a tank where the town could distribute them for irrigation. Garza was obliged to invest 20,000 pesos in repairs over the next five years. ${ }^{69}$ The town made a separate, forty-year (1928-68) contract with Manuel Barragán for the use of the waters by the bottling company-the Compañía de Aguas Gaseosas. ${ }^{70}$ The ejidatarios of the Topo Chico were told to relinquish their hold on the bathhouse and spring waters, and that there was no water in the Río Santa Catarina to irrigate their new fields. ${ }^{71}$ The most they got was permission from the secretary of agriculture and development to build, at their own cost, a horizontal filtration well (galeria filtrante) to collect the water. $^{72}$ They made an effort to secure an industrial concession for the hot springs water, presenting a map from 1904 that showed the hot springs were part of the Río Santa Catarina, and thus national waters they could solicit. ${ }^{73}$ Bathhouse operator J.T. Garza defended his access to the water with a municipal map of Monterrey that 
showed the Arroyo Topo Chico petering out in the irrigated fields of San Nicolás, without reaching the Río Santa Catarina. It was not federal water, he concluded, and therefore ownership by the town, and the lease to the bathhouse and bottling companies, should stand. ${ }^{74}$

For most of the 1920s both Nuevo León and the federal government of Mexico claimed jurisdiction over the springs, using scientific arguments about the origin and destination of the waters. The contracts brokered by the state government of Nuevo León were based on rights and concessions that had yet to be established by the federal government, which by then considered itself the proprietor of the water. In order to award these concessions, and regularize the contracted uses of the water, in August 1929, the Federal Secretaría de Agricultura y Fomento sent engineer Ramón Áviles to conduct a third study of the springs. He spoke with different parties that used the hot springs, took measurements of streamflow and photographs of the installations, drew up maps of the site, and wrote a detailed report. He concluded that both the Ojo Caliente and the Los Baños (Agua Caliente) hot springs were permanent, and the La Saca flowed only when it rained. The Los Baños (Agua Caliente) hot spring was used by the bathhouse, the bottling company, and the townspeople for domestic chores, while Ojo Caliente and La Saca were used to irrigate gardens and orchards. All the water from the three sources was used completely. ${ }^{75}$ Áviles's report concluded that the Topo Chico springs were national waters, and the 1926 presidential declaration of water rights should stand. The town had rights by presidential decree to 2 liters per second (lps) of the Los Baños (Agua Caliente) hot spring for domestic uses. In addition, the engineer assigned 7.92 lps of the water divided among La Saca, Ojo Caliente, and Los Baños to irrigate the twenty-five hectares of orchards and fields for which there was previously no water assigned.

With the submission of Áviles's report, any water use that was not formally recognized by the federal government's secretary of agriculture became illegal, including customary uses that had been practiced by townspeople for generations. Furthermore, with nationalization of the water confirmed by the report, whatever water not assigned by the federal government was up for grabs through a process of concession. Mexican water law held that rights to nationalized water should be awarded to those who had established continuous, peaceful use of that water during the previous five years. According to this formulation, both the town of San Bernabe Topo Chico and the companies could lay claim to the liquid: the water passed through the bottling plant and baths, and then the community used it. Except for the water that ended up inside the bottles, the bathhouse and bottling plant made "nonconsumptive" use of the liquid and handed it over to the community for domestic uses and agriculture.

The nationalization of the Topo Chico springs directly benefitted the companies, and facilitated the long-term shift in control from peasants to industrial capitalists. Shortly after the 1929 report was submitted, the Ministry of Agriculture 
and Development alerted the bottling and bath companies that they would need to solicit a water concession or confirmation of existing use or their access to the springwater would be suspended. ${ }^{76}$ In the same month that the engineer made his survey, the Compañía Topo Chico filed a request that the government recognize its rights to the springwater, claiming that it had used the medicinal waters in the bathhouse since $1886 .{ }^{77}$ For its part, the town of San Bernabe Topo Chico filed a request for a new concession of waters, arguing that it wished to expand the bathhouse to expand curative services to a "public in pain." ${ }^{8}$ At that moment, however, the Ministry of Agriculture and Development overrode the deal brokered by the state of Nuevo León that gave the town the property rights to the bathhouse. The federal government ruled that the owner of the bathhouse was Garza, not the town, and that furthermore he had "acquired the rights to the use of those waters." 79 Also, a concession of 1.396 lps of water from all three springs was awarded to the bottling company, and it was advised that it should no longer pay the 100 pesos a month to the town for the use of the water, for the town was no longer the owner. ${ }^{80}$ The town, seeing the water of the hot springs slip from its hands, demanded its return, accusing the governor of Nuevo León of arbitrarily given water away to "outsiders." ${ }^{1}$

The consolidation of capital's control over the Topo Chico springs in the form of bathing and bottling moved steadily forward despite, and even because of, the revolutionary turmoil and political uncertainties of the teens and early twenties. The reconstruction and strengthening of the nation-state in Mexico carried with it the nationalization of property rights for land and water and, in cases such as Topo Chico, the state facilitated the transfer of common resources to private firms. The Topo Chico bottling company actually expanded its offerings during the revolutionary years to include flavored sodas such as ginger ale ("Yinyereil") and an apple drink called "Eva." It also improved its factory by investing in a metal bottle capping machine. ${ }^{82}$ And, in 1926, the company became the first bottler in Mexico to produce Coca-Cola. ${ }^{83}$

By 1930, after years of neglect, the Compañía de Baños had rehabilitated the bathhouse by laying down tiles and providing mattresses and rugs, and had spruced up the town park, which had been used by the agrarista rebels to graze their horses. Once fixed, a stream of visitors-including foreigners-returned to the baths, lured by their medicinal qualities. ${ }^{84}$ Salubridad Pública monitored the installations, to assure cleanliness and attractiveness for the tourists to the springs, and told the community to scrub the tank where the residual waters from the bottling and bathhouse collected before being sent to the fields. ${ }^{85}$ Bitter residents replied that the only reason it was dirty was because the bottling plant dumped syrups, soap, label glue, and machine oil into it, and demanded that their water be delivered to them first and to the bottling plant later. ${ }^{86}$ Having already won the day, the engineers of the Ministry of Agriculture responded with righteous indignation, labeling the complaints "morally wrong" and calling the townspeople "liars." ${ }^{7}$ The ejidatarios, 
for their part, concentrated their energy on fighting with agricultural producers from neighboring communities for the water of the Río Santa Caterina. ${ }^{88}$

During the next decade, access to the Topo Chico hot springs would narrow even further, as the bathhouse closed due to fading public interest and the bottling industry consolidated its hold over the water. In 1930 the bottling plant of the Compañía Topo Chico entered another period of expansion, and began to export products by road and rail to cities in the states of Nuevo León, Tamaulipas, and Coahuila. The company substituted the older brand of ginger ale with a new product called "Ginger Ale Topo Club." 89 The Coca-Cola Company strengthened its relationship with the Compañía Embotelladora Topo Chico, and its products, introduced in 1926, led the growth. Attracted by the success of the Topo Chico Company, a competing bottling firm pressured the federal government to reassess spring flows once again (the fourth time), and then grabbed the newly identified unassigned water before it arrived to the townspeople, who were now the last in line. Local control of the water for agriculture, drinking, and bathing was no more. Like most cities in Mexico, Monterrey grew rapidly after 1940, incorporating neighboring communities and their lands, and the community of San Bernabé Topo Chico was integrated into the urban sprawl in the 1960 .

\section{CONCLUSIONS}

Governments in Mexico facilitated the business of bottling in Mexico's mineral springs after the revolution (1910-20). In Tehuacán, the federal government's Departamento de Salubridad Pública imposed rules of sanitation and hygiene that helped consolidate the control of large businesses over the production of mineral waters, refrescos, aguas gaseosas, and other diverse bottled drinks. This resulted in the control of the bottling business in that town by the Garci-Crespo company. In Topo Chico, the government deployed the science of hydrology to gradually wrest the spring waters from peasants and ranchers and redirect them to a bathhouse and bottling plants. The Coca-Cola Company eventually took over bottling at the Topo Chico springs, propelling the eventual displacement of all other social actors and uses.

In both Tehuacán and Topo Chico the end result of this dispossession can be seen in the meanings that these two place names carry today: both these words are brand names synonymous for bottled gasified waters. By the 1950s, state intervention in these two mineral springs helped transfer the waters from the hands of local peasants to large industrial companies. Tehuacán's Garci-Crespo company, founded in 1928, grew to be the most important producer of mineral waters in central Mexico, becoming the Peñafiel company in 1948, and eventually forming part of Cadbury Schweppes (1992), and then part of the Dr. Pepper Snapple Group (1995). The spring still bubbles forth deep beneath the bottling plant in a carefully controlled catacomb that can be visited by tourists (but not photographed). In northern 
Mexico a sparkling water is a Topo Chico, a name that is increasingly used in Texas and the rest of the southwestern United States as well. Topo Chico is now the founding brand of the Arca Continental Company, a conglomerate that produces snack foods and is the second largest bottler of Coca-Cola in Latin America..$^{\circ}$

Hydrology and biology accentuated the homogenization of waters, but paradoxically, they also made their heterogeneous qualities more attractive. In Tehuacán, the dangers of biological contamination were identified and combatted, reducing the variable quality of bottled waters, contributing to their standardization and turning them into a kind of public water. At the same time, the mineral waters of Tehuacán and Topo Chico in their commodity form of bottled drinks enjoyed widespread appeal precisely because of their specificity: their mineral content, their particular geological origins (real or imagined), and the idea that these springwaters have unique, culturally rich histories..$^{91}$ The commoditization of these waters did not smooth over their specificity; in fact, it depended on it. 